\title{
The Development of Guided Inquiry-based Worksheet on Colligative Properties of Solution for Chemistry Learning
}

\author{
Shavira Meidina Irham \\ Graduate Student of Chemistry Education \\ State University of Padang \\ Padang, Sumatera Barat, Indonesia \\ shavirameidina@gmail.com
}

\author{
Mawardi \\ Chemistry Education Lecturer \\ State University of Padang \\ Padang, Sumatera Barat, Indonesia \\ mawardianwar@yahoo.com
}

\author{
Budhi Oktavia \\ Chemistry Education Lecturer \\ State University of Padang \\ Padang, Sumatera Barat, Indonesia \\ budhi_okt@yahoo.com
}

\begin{abstract}
This study aims to produce a teaching material in the form of guided inquiry based worksheet and to evaluate its validity, practicality, and effectiveness. The research was conducted using Research and Development (R\&D) model. Development model that is used in this research is a 4-D model (define, design, develop, and disseminate). Validity analysis result showed that moment kappa value is 0.91 , which can be categorized as very high. Practicality analysis result based on teachers response and students showed that practicality value is 0.82, which can be categorized as very high. From effectiveness test, the gain score of student's learning outcome before and after using worksheet in learning is 0.54 , which can be categorized as intermediate and mean of students activity presentation in each meeting is $81 \%$, which can be categorized as very effective. Based on the data, it can be concluded that guided inquiry based worksheet on colligative properties solution are valid, practical, and effective.
\end{abstract}

Keywords-worksheet; guided inquiry; colligative properties solution; validity; practicality; effectiveness

\section{INTRODUCTION}

Chemistry is the study of matter and the changes it undergoes [1]. Learning chemistry is basically learning that most of the discussion topics are abstract and need an understanding in terms of the molecular or sub microscopic concept [2]. One of the chemical material whose characteristics are abstract and need an understanding at the level of sub microscopic is colligative properties solution [3].

The results of interviews with chemistry teachers and students of senior high school revealed that students have difficulties in understanding and analyzing the concepts in colligative properties solution, and students are more likely to memorize, compared to understand the concept. It can be concluded that in learning the material of colligative properties solution, students are still not able to maximize their ability to learn on their own and the students are lack of involvement in the learning process.

Teaching materials have several functions: (1) to reach the competencies to be achieved in learning, (2) to improve student learning outcomes, and (3) to help teachers to manage classes [4]. One of the instructional materials is worksheet. Worksheet contains a set of activities that must be carried out by the students to maximize their understanding of a concept [5]. Worksheet shows advanced phenomenon that are concrete, simple, and related to the concept that will be studied. Based on further observations, students are invited to construct the knowledge gained [6]

In this research, the worksheet on colligative properties was developed follows a guided inquiry learning model that is called as guided inquiry based worksheet. This worksheet was created using guided inquiry cycle, consists of orientation, exploration, concept formation or concept invention, application, and closure. Additionally, the worksheet was developed using the three levels of chemical phenomena that is macroscopic, microscopic, and symbolic. Based on the results of previous research conducted by Bilgin [7], Myers [8] and Parappiliy et al [9] concluded that students who learn to use guided inquiry more easily mastered the concept. Additionally, it can improve students' thinking skills and student learning outcomes, and provide meaningful learning. Based on this, the authors conducted a study to develop a guided inquiry based worksheet on colligative properties solution for chemistry learning. The product was tested for validity, practicality and effectiveness. 
According to Abidin (2014: 149) model of inquiry learning is a learning model that requires students to be able not only to answer questions or get the right answers but also required to conduct a series of investigations, exploration, searching, experiment, search, and research [10]. Based on these explanations, it can be concluded that the inquiry learning puts the teacher not as a source of learning, but rather as a facilitator and motivator of student learning. Therefore, the ability of teachers in questioning technique is the main requirement in the inquiry process. Buck et al states that inquiry learning is the most effective is guided inquiry [11]. Based on this we can conclude that the most suitable level of inquiry on the process of learning for high school students are guided inquiry.

The guided inquiry learning cycle simplest triggered by Lawson and Abraham (1979) consist of the exploration, concept formation, and application [12]. However, Hanson develops a guided inquiry learning cycle into five stage: orientation, exploration, concept formation or concept invention, application, and closure) [13].

Critical thinking questions are used in guided inqury process to guide students' exploration of the models. In broad terms, there are three types of questions that are used, each of them has a different purpose. When students explore from model or information and answer key questions, it means students have already entered the stage of concept formation [14].

According Trianto, worksheet contains a set of activities that must be performed to maximize student understanding in efforts to establish the basic capabilities corresponding indicators of achievement of learning outcomes [15]. The use of worksheets in the learning process is to change the learning pattern of teacher-centered to the student-centered. According to the Ministry of National Education, the structure of the content of worksheet at least include: (1) the title/ identity, (2) the instructions for learning, (3) the competence to be achieved, (4) learning materials, (5) the task or work step, and (6) evaluate [16].

Therefore, the research aimed at producing a quided inquiry based worksheet designed by using all stages of guided inquiry learning cycle. The worksheet is also packed with chemical phenomena involving three levels, namely symbolic, macroscopic and sub-microscopic, or molecular).

\section{RESEARCH METHOD}

\section{A. Research Design}

The type of research is Research and Development (R\&D), i.e. research used to produce a specific product and test the effectiveness of these products [17]. The development model used in this study model 4-D as developed by Thiagarajan, and Semmel Semmel in 1974. The 4-D model consists of four main stages, namely: (1) define, (2) design, (3) develop and (4) disseminate [18].Guided inquiry based worksheet is validated by 4 validators (chemistry lecturers and chemistry teachers) and tested to 4 chemistry teachers and 30 students of class XII SMA 8 Padang.
The research starts from define. Define includes front-end analysis, learner analysis, task analysis, concept analysis and specifying instructional objectives. The second steps is the design. At the stage of design is designing guided inquiry based worksheet on colligative properties solution. Third steps is develop. This phase consists of three steps: expert appraisal, revise, and developmental testing (practicality test). The fourth steps is the disseminate. This phase consists of three steps: validation testing, packaging, diffusion and adoption. The validation testing is used to test its effectiveness. The effectiveness of guided inquiry based worksheet in this study shows the learning outcomes and student learning activities. The last step of the disseminate is packaging, diffusion and adoption. This phase is carried out so that the product can be used by others. However, at this stage the researchers restricted only to the step of dissemination of worksheet through the distribution of a limited number of teachers. This distribution is intended to obtain feedback on the response and worksheets developed. If the target response, the worksheet is good, then the newly performed printing in large quantities and marketing of worksheet so it can be used by a broader target. However, researchers did not do the printing in large quantities and marketing due to time and cost.

\section{B. Instrument}

The instruments used in this study are validation sheet (to chemistry lecturers and chemistry teachers), questionnaire (consisting of the questionnaire responses of teachers and students), and the instrument of effectiveness test (comprising of tests of learning outcomes and student learning activity observation sheet). Validation sheet is used to assess the components of worksheet in terms of content, construct, linguistic, and graphic. The questionnaire aims to determine the practicalities level of guided inquiry based worksheet during the learning process (ease of use worksheet, presentation or contruct of worksheet, and ease of interpretation worksheet). Instrument of effectiveness test is used to know the results of study and observation sheet was used to observe the activity of students and observe the overall learning during use guided inquiry based worksheet. The coverage observed are (1) to observe and analyze the model, (2) to discuss with the group to determine the answers key questions, (3) to ask the teacher, (4) to respond to questions / statements of teachers, and (5) to do the exercise.

\section{Analysis of Validity and Practicality Techniques}

Technical analysis of the data used for the analysis of validity and practicality (questionnaire responses of teachers and students) is by using the kappa moment (k) [19].

\section{Effectiveness Analysis Techniques}

\section{1) Analysis Test Student Results}

Learning is said to be effective if the students after learning are scored above the Minimum Completeness Criteria (MCC) of more than or equal to 60\% [20]. In the learning process by using worksheet said to be effective if it is more or equal to $60 \%$ of students scored $\geq 80$ (MCC of chemistry lessons at school where trial conducted). Analysis of the students' understanding of student learning outcomes can be searched by using the approach proposed by Kunandar percentage [21]. To measure the effectiveness of guided 
inquiry based worksheed to improve cognitive ability can also be analyzed using $\mathrm{N}$-gain formula proposed by Hake [22].

\section{2) Analysis of Student Activities}

Analysis of student activity can be found by using the percentage of the approach proposed by Kunandar [21]. Criteria student activity according to Riduwan [16].

\section{RESULT AND DISCUSSION}

\section{A. Result}

\section{1) Define}

Based on interviews with teachers and students, it can be concluded that the main problem that occurs in school related to teaching materials used during this less actively involve students in the learning process in understanding the colligative properties solution. In addition, materials used have typically involved two levels of the chemical representation is macroscopic and symbolic that cause students to assume that the material colligative properties solution are abstract and difficult to understand. In this study students that will be served as a research subject is class XII high school students aged between 15-17 years. According to Piaget's theory of learning the way of thinking-age children in the formal operational stage of development (intellectual) that children are able to think logically, draw conclusions and interpret.

To analyze the basic competencies and do the translation of the learning indicators. In the task analysis performed basic comptencies analysis. Basic comptencies is based on the analysis contained in the curriculum syllabus 2013.

\section{2) Design}

Having defined the concepts, indicators of learning and the learning objectives formulated, the next step is to design worksheets based guided inquiry. At this stage the resulting initial draft worksheets based guided inquiry that the authoring format is based on manual development of teaching materials, as follows: (1) title / identity of the material, (2) guide student learning, (3) core competence, basic competency, indicator and learning objective, (4) information, (5) models and critical thinking question (key questions), and (6) exercise.

\section{3) Develop}

Worksheet based guided inquiry that has been created is validated by expert appraisal (validator). The results of expert appraisal was conducted to reveal the components of contents, construct, linguistic and graphic of worksheets that have been designed. The results of the validation of the validators of the worksheet based guided inquiry that has been developed as shown in Table I. The following analysis of the questionnaire responses of teachers and students can be seen in Table II. Based on assessment practicalities of worksheet based guided inquiry is obtained very high. From the results of these practicality, the guided inquiry based worksheet can be applied to the learning process in schools.

In validation testing, the product has been revised in the development stage and then implemented on the real target. At the stage of validation testing to test its effectiveness. The effectiveness guided inquiry based worksheet in this study can be seen from learning outcomes (Table III) and student learning activities (Table IV).
TABLE I. The Average Result of VAlidity Test

\begin{tabular}{|l|l|l|}
\hline No & \multicolumn{1}{|c|}{ Validity test } & The average of $\boldsymbol{k}$ value \\
\hline 1. & Contents components & 0.92 \\
\hline 2. & Construct components & 0.89 \\
\hline 3. & Linguistic and graphic components & 0.92 \\
\hline$k$ (moment kappa) & 0.91 \\
\hline \multicolumn{2}{|l|}{ Category } & Very high \\
\hline
\end{tabular}

TABLE II. THE DATA PRACTICALITY OF WORKSHEET

\begin{tabular}{|l|l|l|l|}
\hline No. & Data & Moment Kappa (k) & Category \\
\hline 1. & Teachers & 0.82 & Very high \\
\hline 2. & Students & 0.82 & Very high \\
\hline
\end{tabular}

TABLE III. THE DATA OF STUDENTS LEARNING OUTCOME

\begin{tabular}{|c|c|l|l|}
\hline Test & \multicolumn{1}{|c|}{$\begin{array}{c}\text { The number of students who } \\
\text { completed }\end{array}$} & Average \\
\hline Pre test & $16,67 \%$ & 5 people & 62,8 \\
\hline Post test & $70 \%$ & 21 people & 82,8 \\
\hline
\end{tabular}

In the context of the development of teaching materials, researchers restricted only to the step of dissemination of worksheet through the distribution of a limited number of teachers. Based on the results of the response to the five teachers, we can conclude that this worksheet has been good, complete, and can motivate students to learn, and can guide the students to learn the concept of colligative properties solution so that the students' understanding of the material will increase. In addition, some teachers suggested worksheets for students tested in several schools of different inputs (school with a superior category, medium, low) so they will know how much the effectiveness of the worksheet is able to enhance students' learning activity can be measured.

TABLE IV. RECAPITULATION VALUE OBSERVATION SHEET STUDENTS ACTIVITIES

\begin{tabular}{|l|l|l|l|l|}
\hline \multirow{2}{*}{ No } & \multicolumn{1}{|c|}{ Activities } & \multicolumn{3}{|c|}{ Percentage (\%) } \\
\cline { 3 - 5 } & \multicolumn{1}{|c|}{ I } & \multicolumn{1}{|c|}{ II } & \multicolumn{1}{c|}{ III } \\
\hline 1. & Observing and analyzing models & 83 & 93 & 100 \\
\hline 2. & $\begin{array}{l}\text { Discuss with the group to determine the } \\
\text { answer key questions }\end{array}$ & 80 & 83 & 90 \\
\hline 3. & Asking to the teacher & 63.3 & 66 & 86.7 \\
\hline 4. & $\begin{array}{l}\text { Responding to a question / statement of } \\
\text { teacher }\end{array}$ & 76.7 & 80 & 83 \\
\hline 5. & Doing exercise & 66 & 70 & 86.7 \\
\hline \multicolumn{2}{|l|}{ Average } & 73.8 & 78.4 & 89.2 \\
\hline \multicolumn{2}{|l|}{ Category } & 81 (Very Efective) \\
\hline
\end{tabular}

\section{B. Discussion}

\section{1) Validation}

Validation data of guided inquiry based worksheet obtained from 2 chemistry lectures and 2 chemistry teachers. The selection of four experts is based on the opinion of Sugiyono states that to test the validity of instruments, can be used on expert opinion (judgment experts) that the amount of at least three people. [17].

Based on the Table I, the results of the validation have the validity of the very high category. So, the results of the assessment worksheets that are developed are valid. As presented Arikunto that a product is said to be valid if the product can indicate a condition that is in conformity with the content and construct [24]. Van den Akker also states that the validity refers to the level of a design based on knowledge 
(content validity) and various components related to each other (construct validity) [25]. In other words, a product is said to be valid if the contents of the product in accordance with the theory and the material studied and the components or the product must be consistent and interconnected with each other.

Although the validity of guided inquiry based worksheet on colligative properties solution was produced with very high category, but still there are some components that must be corrected in accordance with the advice given by the validator, are as follows: improve writing sentences on the learning objectives, improve the layout of the worksheet, each sub chapter title material made though more clearly, correct the errors writing $\mathrm{CH}_{3} \mathrm{COO}^{+}$ions into $\mathrm{CH}_{3} \mathrm{COO}^{-}$. In accordance with the advice given by the validator, the revision of the worksheets on colligative properties that will be developed for further tested product.

\section{2) Analysis of Questionnaire Responses Teacher Practicality}

From the results of teacher assessment questionnaire responses obtained an average of 0.82 with a very high category. Based on this, it is known that worksheet is practice. As Sukardi and Neli et al considered the practicalities can be seen from the aspects of ease of use, aspects of the presentation, and the easiness of interpreting [26]. From the aspect of the presentation that the content of the material at worksheet competence achieved is appropriate and the aspects of ease in interpreting that guided inquiry based worksheet is easily interpreted by teachers.

\section{3) Analysis of Questionnaire Responses Student Practicality \\ Based on the practicalities of assessment instruments student questionnaire responses, it is obtained an average kappa moment value of 0.82 (Table II). It is revealed that the worksheet having practicalities of very high category to be used in the learning process. Based on the above it can be concluded that the guided inquiry based worksheet on colligative properties solution can guide students to discover concepts and help students understand the material colligative properties solution.}

\section{4) Effectiveness Test Analysis}

\section{a) Analysis of Student Results}

Based on the data in Table III, it can be concluded that more than $60 \%$ of students who study got results above the MCC is as much as $70 \%$ of the students that as many as 21 people. Based on this, guided inquiry based worksheet effectively used in the learning process. Budimah states that learning is said to be effective if the students after learning scoring above the MCC of more than or equal to $60 \%$ [20]. To measure the effectiveness of teaching materials to improved cognitive ability, test instruments can be used and analyzed by using the formula $\mathrm{N}$-gain [22]. The calculation result obtained $\mathrm{N}$-gain average gained an average gain score of 0.54 . Based on the criteria Hake showed that the effectiveness of teaching materials to increase cognitive abilities fall into the category of the effectiveness of the "intermediate". These results indicate that the guided inquiry based worksheet effectively used in the learning process with the intermediate category. However, it is seen that the results of student learning has increased significantly. Changes in student learning outcomes before and after using guided inqury based worksheet showed visible differences in student learning outcomes at the time of the pre-test and post-test are shown in Table III. Based on the test results of the pre-test, there are only 5 students with study results completed with the average value of grade 62.8. At post test after using guided inquiry based worksheet occurs the increasing grades of 21 students with an average increase in grade to 82.8 . This is consistent with prior works reported that students who learn to use guided inquiry more easily understand the concept, can enhance critical thinking skills (high order thingking) and improve student learning outcomes, as well as providing meaningful learning [7-9].

In terms of the learning experience by using guided inquiry based worksheets, the students gained knowledge on their own construction. In accordance with the theory that describes the knowledge, the students acquired on the construction itself will last longer in the memory of the students, especially when students are given the opportunity to construct their own, meaning many senses are active in receiving information.

\section{b) Analysis of Student Activities}

Based on the observations, it can be concluded that when the learning process is run by using guided inquiry based worksheet, students were enthusiastic and active. When using worksheets, students seem to start first by reading the brief information, observing and analyzing the model, discuss the answer of the critical thinking question (key questions), and do the exercise as well as the matter of applications. In the practicum or doing experiment, students start first by reading the brief information, answered pre-lab questions, doing experiment according to the procedure given, observe and construct understanding by analyzing the data they collect, then answer post the lab question, and then the students also observed macroscopic, microscopic, and symbolic to assist their understanding. The results of observations of learning activities at the first meeting to the third meeting were $77.3 \%$, $78.4 \%$ and $89.2 \%$. The average results of the analysis of student activity obtained when using the percentage of student activity guided inquiry based worksheet is $81 \%$, which means that the effectiveness of the guided inquiry based worksheet, namely the category of "very effective" (Table IV).

According to The College Board (2012: 21) students are often confused when the process of guided inquiry that was first implemented if previously guided inquiry learning was never been implemented [12]. But with the effort and encouragement of teachers, students will be familiar and able to overcome the confusion. Activity is highest at the third meeting. The third meeting was learning activities conducted in the laboratory. The high activity of the students at this meeting was because students were very enthusiastic about doing practical work. According Parappily et al high interest enhances students' thinking skills and better understand what and why students do lab work [9]. 


\section{CONCLUSION}

Based on the research that has been done, it can be concluded that the development of guided inquiry based worksheet on colligative properties solution has very high validity, very high practicality and effectively used in the learning process.

\section{References}

[1] Chang, Raymond. (2003). General Chemistry, The Essential Conceots, Third Edition, Mc Graw Hill, New York

[2] Sunyono. 2012. "Kajian Teoritik Model Pembelajaran Kimia Berbasis Multipel Representasi (SiMayang) dalam Membangun Model Mental Siswa". Artikel disajikan dalam Proseding Seminar Nasional Sains, Universitas Negeri Surabaya, Surabaya, 14 Januari.

[3] Talanquer, Vicente. 2010. "Exploring Dominant Types of Explanations Built by General Chemistry Students". International Journal of Science Education. 32 (18) : 2393-2412

[4] Muslich, Masnur. 2010. Text Book Writing. Jogjakarta: Ar-Ruzz Media Group

[5] Trianto. 2010. Model Pembelajaran Terpadu. Jakarta: Bumi Aksara.

[6] Amri, Sofan. 2013. Pengembangan dan Model Pembelajaran dalam Kurikulum 2013. Jakarta : PT. Prestasi Pustakarya.

[7] Bilgin, Ibrahim. 2009. "The Effects of Guided Inqury Instruction Incorporating, a Cooperative Learning Approach on University Students'Achievement of Acid and Bases Concepts and Attitude Toward Guided Inqury Instruction”. SRE, 4 (10): 1038-1046

[8] Myers, Monypenny, \& Trevathan. 2012. "Overcoming the glassy-eyed nod: an application of process-oriented guided inquiry learning techniques in information technology". $J L D, 5(1): 12-22$

[9] Parappiliy, Maria B., Salim Siddiqui, Marjan G. Zadniq, Joe, dan Lisa Schmidt. 2013. "An Inquiry-Based Approach to Laboratory Experiences: Investigating Students' Ways of Active Learning". International Journal of Innovation in Science and Mathematics Education, 21(5): 42-53.

[10] Abidin, Yunus. 2014. Desain Sistem Pembelajaran dalam Konteks Kurikulum 2013. Bandung: Refika Aditama.

[11] Buck, Laura B., Stacey Lowery Bretz, dan Marcy H. Towns. 2008. Characterizing the Level of Inquiry in the Undergraduate Laboratory. Journal of College Science Teaching September/ October 2008: 52-58.

[12] The College Board. 2012. AP ${ }^{\circledR}$ Chemistry Guided-Inquiry Experiments: Applying the Science Practices (Teacher Manual). New York: The College Board

[13] Hanson, David. M. 2005. Designing Process-Oriented Guided-Inquiry Activities. In Faculty Guidedbook: A Comprehensive Tool For Improving Faculty Performance, ed. S. W. Beyerlein and D. K. Apple. Lisle, IL: Pacific Crest

[14] Hanson, David. M. 2006. Instructor's Guided to Process-Oriented Guided-Inquiry Learning. Lisle, IL: Pacific Crest

[15] Trianto. 2010. Model Pembelajaran Terpadu. Jakarta: Bumi Aksara.

[16] Kemendiknas. 2010. Juknis Pengembangan Bahan Ajar SMA. Jakarta : Direktorat Pembinaan SMA.

[17] Sugiyono. 2006. Metode Penelitian Pendidikan. Bandung: Alfabeta.

[18] Thiagarajan, Sivasailam, Dorothy S. Semmel, dan Melvyn I. Semmel. 1974. Instructional Development for Training Teachers of Exceptional Childern A Sourcebook. Indiana: Indiana University Bloomington.

[19] Boslaugh, Sarah dan Paul A. W. 2008. Statistics in a Nutshell, a desktop quick reference. Beijing, Cambridge, Famham, Köln, Sebastopol, Taipei,Tokyo: O'reilly.

[20] Budimah, Herpratiwi, dan Undang Rosidin. 2014. “ Pengembangan Modul Pembelajaran Ipa Berbasis Karakter Materi Kalor SMP Kelas VII Di Bandar Lampung. Jurnal Sains dan Pendidikan . 1 (1) : 1-8
[21] Kunandar, 2007. Guru Profesional Implementasi Kurikulum Tingkat Satuan Pendidikan dan Sukses dalam Sertifikasi Guru. Jakarta: RajaGrafindo Persada.

[22] Hake. 2002. Relationship of Individual Student Normalized Learning Gains in Mechanics with Gender, High-School Physics, and Pretest Scores on Mathematics and Spatial Visualization. Indiana University.

[23] Riduwan. 2009. Belajar Mudah Penelitian Untuk Guru-Karyawan dan Peneliti Pemula. Bandung: Alfabeta.

[24] Arikunto, Suharsimi. 2005. Dasar-dasar Evaluasi Pendidikan (edisi revisi). Jakarta: Bumi Aksara.

[25] Van den Akker, Jan. 1999. Design Approaches and Tools in Education and Training. Dordrecht: Springer Science Business Media, B.V.

[26] Sukardi. 2011. Evaluasi Pendidikan, Prinsip, Dan Operasionalnya. Yogyakarta: Bumi Aksara. 